\title{
Habitat Evaluation for Reintroduced Crested Ibis (Nipponia nippon) in Dongzhai National Nature Reserve, China, Based on a Maximum Entropy Model
}

\author{
Liumeng Zheng', Yanmei Wang', Jiagui Zhu' ${ }^{2}$, Ke Wang', Dejing Cai' \\ Yuanzhao Qin ${ }^{3}$, Yuming Guo ${ }^{3}$, Hongxing $\mathrm{Niu}^{1, *}$ and Yanzhen Bu${ }^{1, *}$ \\ ${ }^{1}$ College of Life Sciences, Henan Normal University, Xinxiang, Henan Province \\ 453007, China \\ ${ }^{2}$ Administration Bureau of Dongzhai National Nature Reserve, Luoshan, Henan \\ Province 464236, China \\ ${ }^{3}$ Administration Bureau of Xinxiang National Nature Reserve, Xinxiang, Henan \\ Province 453000, China
}

Liumeng Zheng and Yanmei Wang contributed equally to this work.

\begin{tabular}{l} 
Article Information \\
Received 19 December 2017 \\
Revised 14 February 2018 \\
Accepted 17 March 2018 \\
Available online 24 May 2018 \\
Authors' Contribution \\
\hline JZ and WK conceived the study. DC, \\
LZ, YW, YQ and YG analyzed the \\
data and wrote the manuscript. HN \\
and YB approved the final version. \\
Key words \\
\hline Nipponia nippon, Habitat suitability, \\
MaxEnt, Dongzhai, Reintroduction.
\end{tabular}

\begin{abstract}
A B S T R A C T
Crested ibis (Nipponia nippon) is globally endangered due to habitat loss and destruction. In 2007, a reintroduction project was implemented in Dongzhai National Nature Reserve, Henan Province, and 78 crested ibises were released between 2013 and 2015, with the aim of establishing a self-sustaining wild population outside the Qinling Mountains, where crested ibis was first reintroduced. The aim of this study was to detect suitable habitat areas, and evaluate the factors affecting the distribution of the crested ibis. We used a maximum entropy model with seven environmental variables to evaluate habitat suitability. Our results indicate that the current reserve may be too small to meet the crested ibises' needs in the future, and we believe that more ibises will disperse outside the reserve as the population expands. The distribution of crested ibises in the Dongzhai Reserve area was mainly affected by altitude, followed by distance to forest, and distance to roads. Notably, our study confirmed that the crested ibis has adapted and regained the habit of living at low elevations in the Dongzhai Reserve. Although most suitable habitat was found inside the nature reserve, a large proportion of suitable habitat was also found outside of the reserve. In addition, we found evidence that crested ibises were fairly tolerant to human disturbances, such as presence of roads. As the population of crested ibises expands, more may move outside of the nature reserve. It is, therefore, important to also implement crested ibis conservation strategies such as public outreach and surveillance outside of the nature reserve, as well as continuing conservation efforts inside of the nature reserve.
\end{abstract}

\section{INTRODUCTION}

$\mathrm{R}$ eintroduction is defined as the release of a species in its previous distribution range in order to establish a selfsustaining wild population (IUCN/SSC, 2013). Worldwide, species reintroductions have increased rapidly over the past few decades as a measure of conserving endangered species (Fischer and Lindenmayer, 2000; Seddon et al., 2007), and play an important part in bird conservation (Bozzuto et al., 2017; Carter and Newbery, 2004). Habitat

\footnotetext{
* Corresponding authors: hongxingniu@htu.cn; buyanzhen@htu.cn 0030-9923/2018/0004-1319 \$ 9.00/0

Copyright 2018 Zoological Society of Pakistan
}

quality directly affects the distribution, population density, reproductive success and adult survival in birds (Cedy, 1985). It is essential to provide adequate suitable habitat for the conservation translocation of endangered species, which is usually an intentional movement and release of organism for conservation objective (IUCN/SSC, 2013).

Habitat assessment can provide spatial distribution information of habitat quality of target species, and it can provide a decision basis for wildlife conservation and management (Jin et al., 2008). Species distribution models (SDMs) can estimate the relationship between species distribution data (presence or absence) and the environmental and/or spatial characteristics of those sites (Elith and Leathwick, 2009; Franklin, 2009). In recent years, SDMs have been widely applied by ecologists to 
clarify habitat ranges and characteristics that are important for target species or populations (Elith and Leathwick, 2009). The maximum entropy model (MaxEnt) is an SDM that utilizes the principle of maximum entropy to determine statistical relationships between presence locations and the environment by comparing the environment where an organism is found to the available environment (Phillips et al., 2006). MaxEnt can model species distributions without absence data (Phillips and Miroslav, 2008; Elith et al., 2011, 2006), and often has better performance in accuracy than other SDMs with limited data (Hernandez et al., 2006; Fonderflick et al., 2015). Logistic outputs of MaxEnt are continuous raster data ranging from 0-1 probability of species presence, and a value closer to one indicates higher probability that the species will appear at the location represented by that raster cell. The probability of occurrence is related to the availability of quality habitat (Merow et al., 2013), therefore the logistic output of Maxent predictions can be regarded as indices of habitat suitability (Kebede et al., 2014; Latif et al., 2015; Sangermano et al., 2015).

The crested ibis (Nipponia nippon) was once widely distributed in eastern Asia. It historically nested in the Russian Far East, Japan, and China, and occurred as a non-breeding visitor to the Korean peninsula (BirdLife International, 2001). In the mid-20th century, the crested ibis became extinct in most of its former range due to deforestation and habitat destruction, as well as changes in farming practices (Ding, 2010). The species was even classified-as extinct in the wild before a single relict population of seven birds (two pairs and three fledging) was re-discovered in Yangxian, Shaanxi Province, in central China in 1981 (Ding, 2010). The first reintroduction of crested ibis was successfully implemented in Zhaigou village, Qinling area, in 2007 (Huo et al., 2014; Yu et al., 2009). Through such reintroduction projects, the population and distribution of this species have increased, and the species distribution has expanded in the Qinling Mountains (Wang et al., 2014; Wu et al., 2017).

Since the wild population is restricted to the Qinling area, the crested ibis is vulnerable to natural disasters and epidemics (Ding, 2010). A reintroduction program was implemented in Dongzhai National Nature Reserve, Luoshan County in Henan Province, China, in 2007, in order to establish a new wild population in the Dabie Mountains. The State Forestry Administration transferred a total of 17 crested ibis (four from the Beijing Zoo, 13 from Japan) to the reserve in 2007, and through captive breeding, the population increased to 132 birds by February 2013. The size of this captive population was sufficient for the first phase of the reintroduction program, which included releasing the captive-bred ibises to the wild, and observing the survival and reproduction of released individuals in the natural environment. From 2013 to 2015, 78 captive-bred individuals ( 34 in 2013, 26 in 2014 and 18 in 2015) were released to the wild after a 7-9 month period of acclimation.

Current studies on the habitat assessment of ibis are focused on the Qinling area (BirdLife International, 2016), located in the western mountainous plateau sub-region of China, while the Dongzhai Reserve is located in the eastern hills and plains sub-region of China (Zhang, 1997). These two environments differ in both geography and climate (Supplementary Table I). As this is the first crested ibis re-introduction project implemented outside the Qinling Mountains, it is of great importance to understand the habitat suitability for crested ibis in Dongzhai. In this study, we use the MaxEnt model to evaluate the habitat suitability for crested ibis in Dongzhai using presenceonly data of released individuals, to achieve the following objectives: (1) evaluate the quantity inside versus outside the reserve and the distribution of highly suitable habitat, which can be used to predict the distribution trend of wild crested ibis; and (2) determine the main factors influencing the habitat suitability for ibis in the region.

\section{MATERIALS AND METHODS}

\section{Study area}

The Dongzhai National Nature Reserve $\left(31^{\circ} 28^{\prime}-\right.$ $32^{\circ} 09^{\prime} \mathrm{N}, 114^{\circ} 18^{\prime}-114^{\circ} 30^{\prime} \mathrm{E}$, area of $468 \mathrm{~km}^{2}$ ) is located on the northern slopes of the western Dabie Mountains in Luoshan County, Henan Province, China (Fig. 1A). The reserve is located in a transitional area between subtropical and temperate zones, with a mean annual temperature of $15.1^{\circ} \mathrm{C}$, and annual precipitation of $1209 \mathrm{~mm}$, and the elevation ranges from 44 to $834 \mathrm{~m}$. More than $70 \%$ of the area is covered by vegetation with north-south intersection characteristics. The forested vegetation is predominantly composed of oak (Quercus spp.), Masson's pine (Pinus massoniana), dyetree (Platycarya strobilacea), beautiful sweetgum (Liquidambar formosana), and hupeh rosewood (Dalbergia hupeana) (Li et al., 2012).

The study area (center $31^{\circ} 55^{\prime} 40^{\prime \prime} \mathrm{N}, 114^{\circ} 18^{\prime} 06^{\prime \prime} \mathrm{E}$, a total of $2826 \mathrm{~km}^{2}$ ) was generated by standard distance with three standard deviations using Spatial Analysis Tools in ArcGis10.0 (Environmental Systems Research Institute, Inc, Redlands, USA). This area includes $99 \%$ of the locations of crested ibis in the Dabie Mountains, covering the initial observed foraging, roosting and breeding habitat of the ibis from October 2013 to August 2016 (Fig. 1B). 


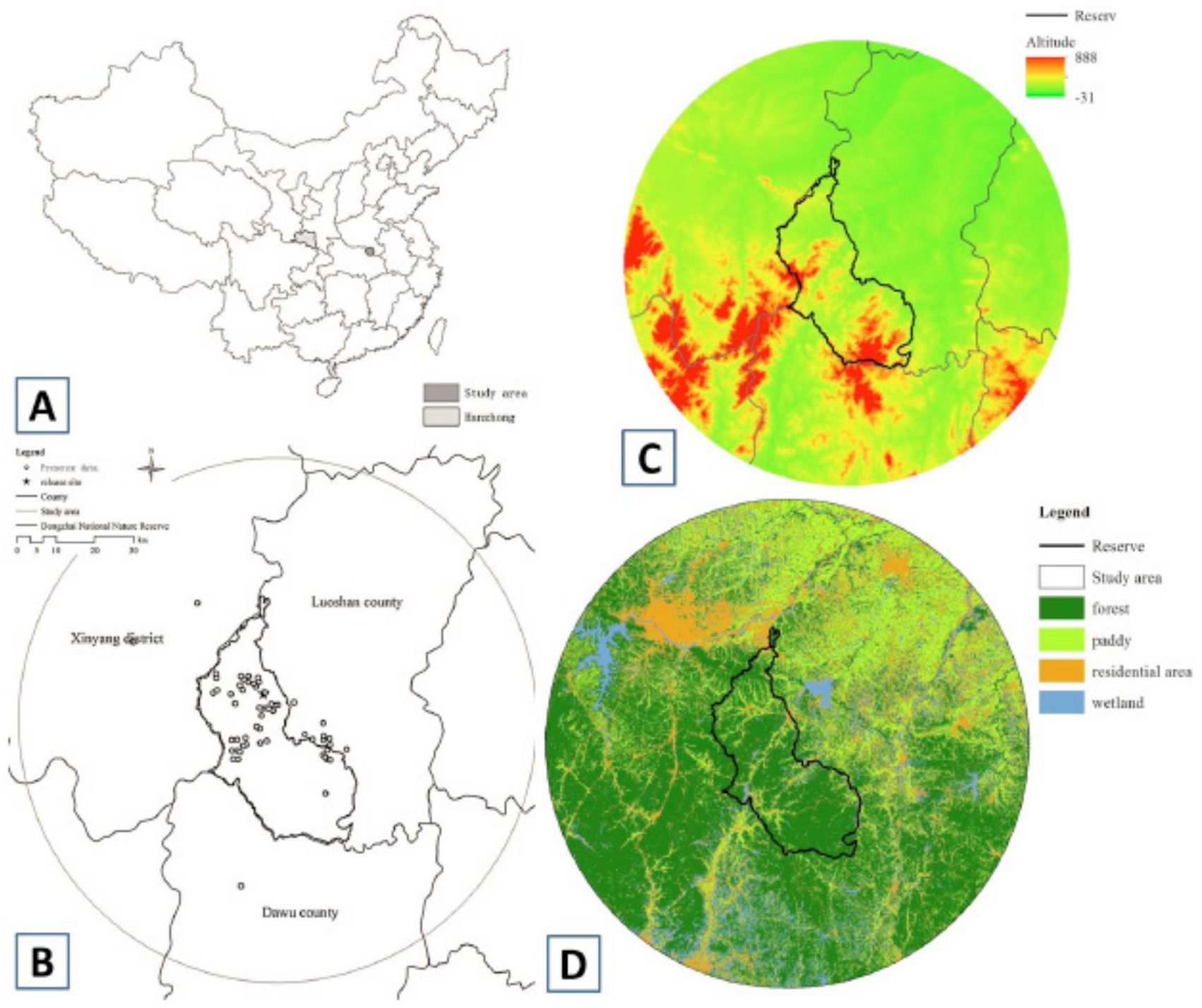

Fig. 1. Study area: A, the mainly distribution area of wild crested ibis in Qinling Mountain, Shaanxi Province, and the study area of reintroduction population in Dabie Mountain; B, the dispersal and habitat evaluation area of reintroduced crested ibis in Dongzhai National Nature Reserve; $\mathbf{C}$, the elevation of study area; $\mathbf{D}$, the land cover of the study area.

\section{Release and monitoring of crested ibis}

The first batch of 34 birds was hard released on 10, 2013 , and the second batch of 26 birds was soft released between August 12 and 26, 2014. Before they were released into wild, all birds were acclimated in semi-natural cages. In the hard release, we opened the door of semi-natural cages, and the crested ibises were driven from the cages into the wild by the breeder. In contrast, in the soft release, the crested ibises were lured out of their cages using food placed at the door and outside the cage after opening the gate. Using this soft release, it took two weeks for all the 26 birds to leave the cages. In total, six of 34 individuals (mean weight $1.67 \pm 0.12 \mathrm{~kg}$ ) released in 2013 were fitted with satellite transmitters weighing $22 \mathrm{~g}$ (North Star Ltd., US), ten of 26 in 2014 were fitted with lightweight radio weighing 19 g (AI-2B, Holohil Systems Ltd., Canada, $\mathrm{n}=5$, mean weight of ibises $1.73 \pm 0.17 \mathrm{~kg}$ ) or satellite transmitters weighing $25 \mathrm{~g}$ (Hunan Global Messenger Co., Ltd., China, $\mathrm{n}=5$, mean weight of ibises $1.61 \pm 0.17 \mathrm{~kg}$ ) before being released into the wild. Since the first release, we extensively monitored the reintroduced population using the transmitters, field tracking surveys, reliable sightings and interviews with local residents. The satellite transmitters, powered by solar panels, sent data every three or four days, as the back feathers covered the solar panel, the subsequent signal could not be sent out after 
about a month or so. The lightweight radio transmitters powered by battery, and most of the presence sites of the crested ibis were identified by the triangulation method using radio signals. Accurate geographical coordinate data was measured by handheld GPS tracker (eXplorist 510, Magellan, Camino Real, Santa Clara, USA) after the birds flew away when it was feasible.

\section{Data sets}

In total, 664 GPS locations were recorded from November 2013 to December 2015, and 112 locations were obtained after deleting duplicate record points and merging locations within $100 \mathrm{~m}$ in ArcGIS10.0. Eight predictor variables were used in this study (Table I): a) terrain factors: altitude (Alt), slope (Slp) and aspect (Asp), the Alt is always considered an important variable in existing studies of crested ibis (Ding, 2004; Li et al., 2006) and it might represent the vegetation particularly the wetland distribution in this study, and Slp and Asp influenced the nest selection of crested ibis (Ding, 2004). b) human disturbance factors: distance to road (DisR) and distance to village (DisV), the DisR and DisV represented the interference of human activities on the crested ibis (Zhang et al., 2017; Li et al., 2002) and (c) land cover factors: distance to forest (DisF), distance to wetland (DisW) and distance to paddy fields (DisP), the land cover reflects the features of the site of the crested ibis, crested nesting and roosting in forest, and mainly foraging in paddy and wetland. Terrain factors were obtained from ASTER GDEMV2 DEM data $(30 \mathrm{~m} \times 30 \mathrm{~m}$ resolution), downloaded from the Geospatial Data Cloud site, Computer Network Information Center, Chinese Academy of Sciences (http://www.gscloud.cn, accessed April 21, 2016). The elevation data were directly obtained from DEM data, and the slope and aspect data were obtained using the surface analysis in Spatial Analysis tools in ArcGIS10.0 (Fig. 1C). The road data were obtained from the Geographical Information Monitoring Cloud Platform (http://www.dsac.cn/DataProduct). A Landsat-8 Operational Land Imager (OLI) image (path 123, row 38, 16/4/2015) was downloaded from the Institute of Remote Sensing and Digital Earth, Chinese Academy of Sciences (http://ids.ceode.ac.cn/, accessed May 2, 2016). The remote sensing imagery was interpreted by classification workflow with training data in ENVI 5.1 (Exelis Visual Information Solutions, Inc., Tysons Corner, Virginia, USA). We generated real ROI surface data by field survey and evaluated the classification accuracy by confusion matrix, and the overall classification accuracy reached $95.85 \%$. Because the crested ibis has different habitat preferences for breeding, foraging and roosting, the land cover was classified as forest land, wetland, paddy field and residential area in ENVI 5.1 (Fig. 1D). Subsequently, the classification results were imported into ArcGIS10.0 to generate a Euclidean distance raster layer for each category. The cross-correlations between variables were examined by Pearson's (Supplementary Table II). All variables correlations were less than $|0.7|$, except that between DisP and Alt, therefore, the DisP was removed in the MaxEnt model.

Table I.- The environmental variables considered used in the Maxent model to predict the habitat suitability for crested ibis.

\begin{tabular}{lllcccc}
\hline Code & Variable & Type & Unit & Range & Mean & SD \\
\hline Alt & Altitude & Continuous & $\mathrm{m}$ & $31 \sim 888$ & 147 & 117 \\
Slp & Slope & Continuous & $\circ$ & $0 \sim 60$ & 9.8 & 7.5 \\
Asp & Aspect & Continuous & $\circ$ & $0 \sim 360$ & 179 & 104 \\
DisR & $\begin{array}{l}\text { Distance to } \\
\text { road }\end{array}$ & Continuous & $\mathrm{m}$ & $0 \sim 8721$ & 1630 & 1469 \\
DisF & $\begin{array}{l}\text { Distance to } \\
\text { forest }\end{array}$ & Continuous & $\mathrm{m}$ & $0 \sim 3216$ & 128 & 220 \\
DisW & $\begin{array}{l}\text { Distance to } \\
\text { wetland }\end{array}$ & Continuous & $\mathrm{m}$ & $0 \sim 5276$ & 535 & 717 \\
DisV & $\begin{array}{l}\text { Distance to } \\
\text { village }\end{array}$ & Continuous & $\mathrm{m}$ & $0 \sim 3792$ & 491 & 527 \\
\hline
\end{tabular}

\section{Habitat suitability model}

We ran the MaxEnt model 10 times, with a different random training dataset $(70 \%, \mathrm{n}=78)$ and testing dataset $(30 \%, \mathrm{n}=34)$ for each replication. We set 10,000 randomly generated background points and a maximum of 5,000 iterations, with all other settings as the defaults in MaxEnt (Phillips and Miroslav, 2008). To evaluate the predictive ability of the MaxEnt models, we used the Area Under Curve (AUC) of the Receiver Operating Characteristic (ROC) curve technique (Anderson et al., 2006; Phillips et al., 2006). The value of AUC generally ranges between 0.5 and 1 , and is a measure of the discrimination ability of the model (Fielding and Bell, 1997). Values less than 0.5 are no better than random, values between 0.5 and 0.7 indicate a rather low accuracy, values between 0.7 and 0.9 indicate that the models are useful for some purposes, and values above 0.9 represent high accuracies (Swets, 1988). The importance of each environmental variable for the development of the model was evaluated using the built-in Jackknife (Phillips et al., 2006; Liu et al., 2017).

The results of the habitat suitability for the crested ibis were in Logistic format, and the output data were continuous raster data of probability of presence (ranging from 0 to 1 ). We assumed that the probability of occurrence was related to the availability of quality habitat for the crested ibis. Therefore, the higher the probability 
of occurrence, the higher quality the habitat available for the species (Sangermano et al., 2015). We used two threshold values generated by Maxent to discretized the model predictions into least suitable, moderately suitable, and most suitable (Kebede et al., 2014).

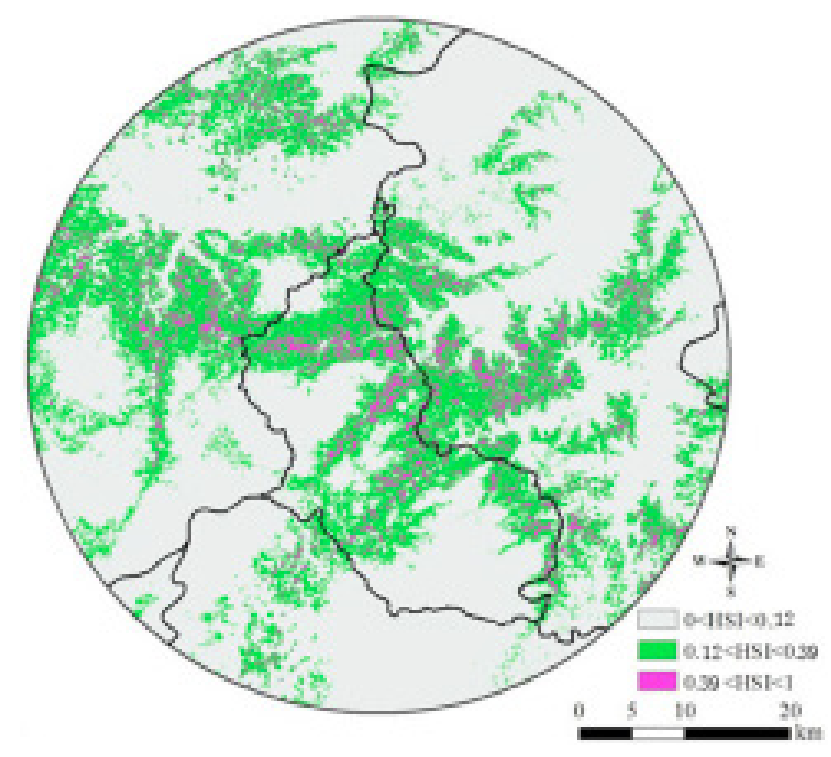

Fig. 2. Habitat suitability map for crested ibis. The map of suitable habitat distribution is divided into three classes: least suitable $(0<$ HIS $<0.12)$, moderately suitable $(0.12<$ HIS $<0.39)$, and most suitable $(0.39<$ HIS $<1)$.

Table II.- Area of suitable habitat in the study area, and the proportion of each category, respectively.

\begin{tabular}{lcccc}
\hline & $\begin{array}{c}\text { Total } \\
\text { area }\end{array}$ & $\begin{array}{c}\text { Least } \\
\text { suitable }\end{array}$ & $\begin{array}{c}\text { Moderately } \\
\text { suitable }\end{array}$ & $\begin{array}{c}\text { Most } \\
\text { suitable }\end{array}$ \\
\hline Inside of & 468.5 & 253.0 & 180.0 & 35.5 \\
reserve & $(16.6 \%)$ & $(13.2 \%)$ & $(23.3 \%)$ & $(27.3 \%)$ \\
Outside of & 2356.1 & 1668.1 & 593.7 & 94.3 \\
reserve & $(83.4 \%)$ & $(86.8 \%)$ & $(76.7 \%)$ & $(72.7 \%)$ \\
Study area & 2824.6 & 1921.1 & 773.7 & 129.9 \\
& $(100 \%)$ & $(100 \%)$ & $(100 \%)$ & $(100 \%)$ \\
\hline
\end{tabular}

\section{RESULTS}

The model for crested ibis produced a training AUC value of $0.923 \pm 0.006$ and a testing AUC value of $0.863 \pm 0.060$, indicating that the MaxEnt model had high prediction accuracy. The minimum training presence logistic threshold and maximum test sensitivity plus specificity logistic threshold values were 0.12 and 0.39 . The polygons with probability value of presence between 0.12 and 0.39 were regarded as suitable habitat patches for crested ibis, and the patches with value greater than 0.39 were regarded as optimum habitat (Fig. 2).

The projected suitable habitats for the species were mainly located within the low altitude areas, and were mainly distributed in the northern and eastern parts of the Dongzhai Reserve (Table II). The total available habitat in the study area reache to $903.5 \mathrm{~km}^{2}$, comprised by 215.5 $\mathrm{km}^{2}$ in the reserve and $688 \mathrm{~km}^{2}$ outside.

The percent contributions of variables to the model indicate that altitude (Alt) was the primary factor contributing to the model, followed by distance to forest (DisF) and distance to roads (DisR). And permutation importance indicate that Alt, DisF and Slp were the three most important variables (Table III). The environmental variable with highest gain when used in isolation was Alt, which therefore appears to have the most useful information by itself. The environmental variable that decreased the gain the most when it is omitted is Alt, which therefore appears to have the most information that isn't present in the other variables (Fig. 3).

Table III.- Variable permutation importance and percent contribution for the crested ibis suitability models.

\begin{tabular}{lcc}
\hline Variable* $^{*}$ & $\begin{array}{c}\text { Percent } \\
\text { contribution }\end{array}$ & $\begin{array}{c}\text { Permutation } \\
\text { importance }\end{array}$ \\
\hline Alt & 54.8 & 47.6 \\
DisF & 22.8 & 27.5 \\
DisR & 8.9 & 5.9 \\
DisW & 2.9 & 12 \\
Slp & 7.4 & 2.1 \\
Asp & 2 & 2.3 \\
DisV & 1.2 & 2.6 \\
\hline
\end{tabular}

*Variables explained in Table I. The top three predictors are highlighted in bold.

\section{DISCUSSION}

The MaxEntmodels created for crested ibis in this study were well supported and applicable to the species analyzed according to high AUC values. Our results demonstrate that the proportion of suitable habitats inside the Dongzhai Nature Reserve is only $23.8 \%$ of that in the study area. In addition, the distribution of suitable habitat in the reserve is uneven, with the increase in the number of crested ibises in the wild, and more releases of captive individuals in the future; there could be a very high density of crested ibises in the reserve in future. On the other hand, although the proportion of suitable habitat outside of the reserve was lower than inside, the area of suitable habitat outside of the reserve was three times larger than inside the reserve. 

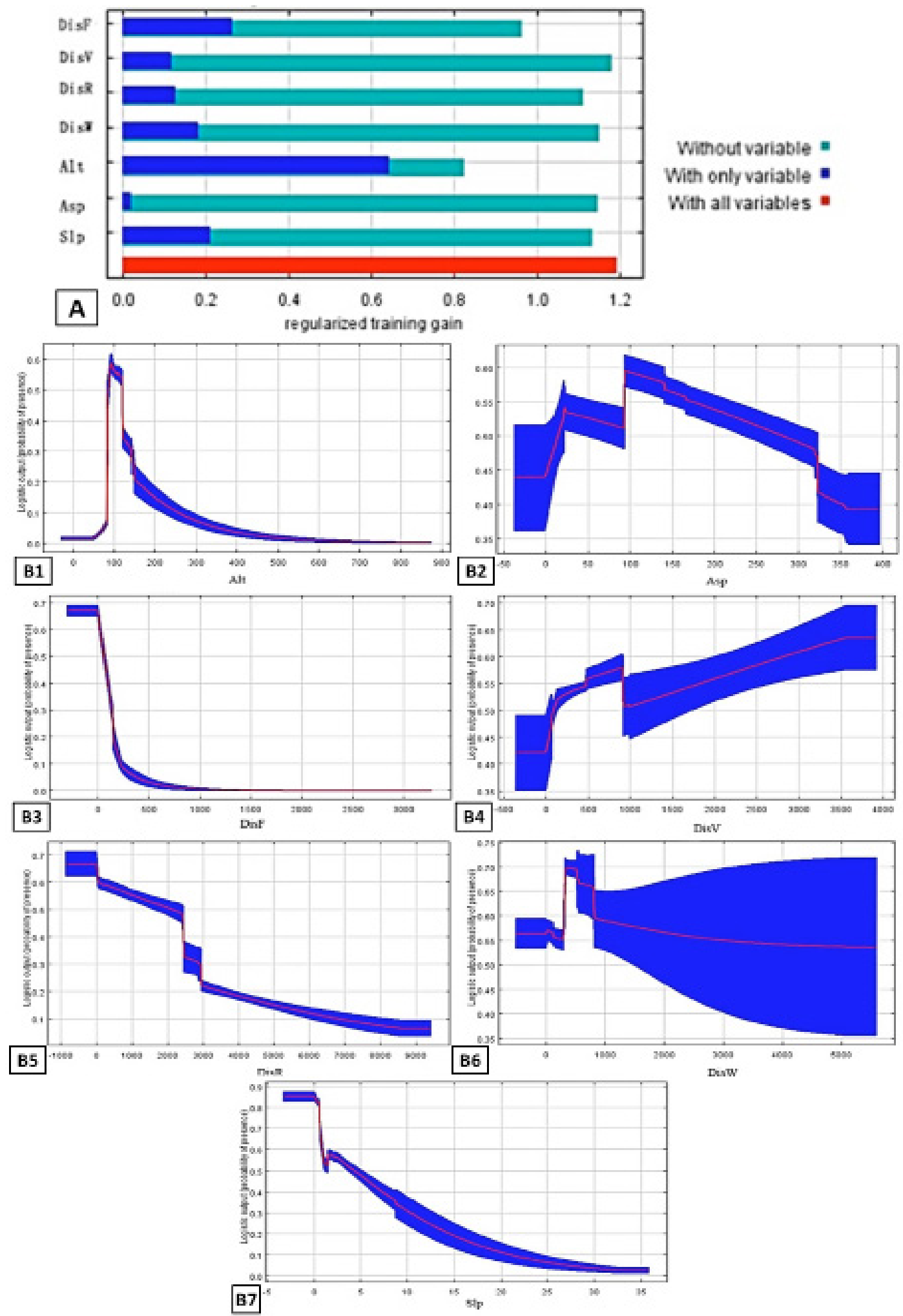

Fig. 3. Results of MaxEnt models: A, Jackknife test of variable importance. Codes of the variables are shown in Table I; B, relationship between main environmental variables and habitat suitability for crested ibis. 
In addition, some of the crested ibises have already spread beyond the existing protected areas in the Dongzhai Reserve. Therefore, we believe that more crested ibises will spread to suitable habitats outside the protected area in the future. This requires additional conservation measures from the local government and wildlife management authorities, including expanding the scope of crested ibis protection efforts, public outreach, and strengthening the surveillance of the areas surrounding reserve.

Altitude was the main environmental factor influencing the habitat suitability for crested ibis in the study area. The most suitable elevation was found to be approximately $100 \mathrm{~m}$ a.s.l. We believe this may be related to several factors. First, the crested ibises were captive bred and acclimated in the area at an altitude of $120 \mathrm{~m}$ a.s.l., and as such, they adapted to the low altitude. Second, the foraging habitats of crested ibis, such as paddy fields and wetlands, were generally distributed in areas with low altitudes. Lastly, because of long-term captive breeding, most of the released crested ibis were mainly active around the aviary (within $15 \mathrm{~km}$ ), and did not spread to the southwest area of high altitude. The optimal elevation in Dongzhai was lower than that in the Qinling Mountains, which ranged from $500 \mathrm{~m}$ to $800-1200 \mathrm{~m}$ (Li et al., 2002; Yan et al., 2015). This may be because the average elevation of the study area was lower than that in the Qinling Mountains, which led to most paddy fields and wetland distributed at low elevation of 100-120 $\mathrm{m}$ in Luoshan but relatively higher elevation such as 650-800 $\mathrm{m}$ in Qinling Mountains (Yan et al., 2015). In addition, a previous study showed that the crested ibis historically lived at altitudes of 200-300 m a.s.1., which may explain why we found a relatively low optimal elevation in our study (Li et al., 2009). We believe that the crested ibis has adapted, and regained the habit of living at lower elevations in the Dongzhai Reserve.

Forests provide a place to avoid the risk of predation. The roosting trees and nest trees of crested ibises were mainly distributed in the hillside forest (Liu et al., 2006; Ma et al., 2001). Preferred foraging habitats for the crested ibis were usually those where ibises could easily scan the horizon(Ma et al., 2001; Zhao et al., 2010). In this study, the contribution and importance of distance to forest land was second to elevation in the MaxEnt model. Crested ibises usually forage in paddy fields, rivers, reservoirs and other wetlands, where they may be easily discovered by raptors (e.g., golden eagle, Aquila chrysaetos). At the first release, we observed that the first crested ibis fly out was attacked by a golden eagle. Thus, land that is close to forest cover may be more suitable for crested ibises, as staying close to the forest can help crested ibises conceal themselves and avoid predation by raptors. There are many individuals of different raptor species in the Dongzhai Reserve (Xi et al., 2013); therefore, pressure from predators may greatly influence habitat selection of crested ibis.

The DisR variable (distance to roads) represents human disturbance in this study. The habitat suitability for crested ibis was negative correlated to the DisR. This indicates that crested ibis preferred nesting and foraging near humans, and had a certain tolerance to human disturbance. The roads in mountainous areas in China, such as that of our study site, are usually built along the river, and paddy fields are often distributed near the road. The higher habitat suitability in the near-road areas may be attributed to the foraging habitats are mainly distributed near the road.

\section{CONCLUSION}

We evaluated the habitat suitability for crested ibis in the Dongzhai Reserve using the MaxEnt model. The results indicate that the area of habitat available for crested ibises in the periphery of the reserve was three times that inside the reserve, and large patches of suitable habitat exist to the northeast and northwest of the reserve. We recommend that local authorities and reserve management staff strengthen public awareness and wildlife management in these potential habitats. The main environmental factors influencing the habitat quality for crested ibis in Dongzhai were altitude, distance to forest and distance to roads. Our results support previous studies that the crested ibis historically lived at low elevations with abundant paddy fields and wetlands, and we found that crested ibises had the ability to regain the habit living in a human-dominated, village ecological environment within a short time.

\section{ACKNOWLEDGEMENTS}

We would like to thank Zhu Honglei of Henan Normal University for assistance with the use of the geographic information systems, and Wu Jie of Henan Normal University for assisting in collecting data for this study. We would like to thank Editage (www.editage.com) for English language editing.

\section{Supplementary material}

There is supplementary material associated with this article. Access the material online at: http://dx.doi. org/10.17582/journal.pjz/2018.50.4.1319.1327

\section{Statement of conflict of interest}

The authors declare that there is no conflict of interests regarding the publication of this article. 


\section{REFERENCES}

Anderson, P.R., Dudík, M., Ferrier, S., Guisan, A., Hijmans, R.J., Huettmann, F., Leathwick, J.R., Lehmann, A., Li, J., Lohmann, L.G., Loiselle, B.A., Manion, G., Moritz, C., Nakamura, M., Nakazawa, Y., Overton, J.M., Peterson, A.T., Phillips, S.J., Richardson, K., Scachetti-Pereira, R., Schapire, R.E., Soberón, J., Williams, S., Wisz, M.S. and Zimmermann, N.E., 2006. Novel methods improve prediction of species' distributions from occurrence data. Ecography, 29: 129-151. https:// doi.org/10.1111/j.2006.0906-7590.04596.x

BirdLife International, 2001. Threatened birds of Asia: the birdlife international red data book. BirdLife International, Cambridge, UK.

BirdLife International, 2016. Species factsheet: Nipponia nippon. Available at: http://www.birdlife. org/ (Accessed 16 Dec 2017).

Bozzuto, C., Hoeck, P.E.A., Bagheri, H.C. and Keller, L.F., 2017. Modelling different reintroduction strategies for the critically endangered Floreana mockingbird. Anim. Conserv., 20: 144-154. https:// doi.org/10.1111/acv.12299

Carter, I. and Newbery, P., 2004. Reintroduction as a tool for population recovery of farmland birds. Ibis, 146: 221-229. https://doi.org/10.1111/j.1474919X.2004.00353.x

Cedy, M.L., 1985. Habitat selection in birds, $1^{\text {st }}$ ed. Academic Press, London.

Ding, C.Q., 2004. Crested ibis research. Shanghai Science and Education Press, Shanghai.

Ding, C.Q., 2010. Crested ibis. Chin. Birds, 1: 156-162. https://doi.org/10.5122/cbirds.2010.0009

Elith, J., Graham, C.H., Anderson, P.R., Dudík, M., Ferrier, S., Guisan, A., Hijmans, R.J., Huettmann, F., Leathwick, J.R., Lehmann, A., Li, J., Lohmann, L.G., Loiselle, B.A., Manion, G., Moritz, C., Nakamura, M., Nakazawa, Y., Overton, J.M., Peterson, A.T., Phillips, S.J., Richardson, K., Scachetti-Pereira, R., Schapire, R.E., Soberón, J., Williams, S., Wisz, M.S. and Zimmermann, N.E., 2006. Novel methods improve prediction of species' distributions from occurrence data. Ecography, 29:129-151.

Elith, J. and Leathwick, J.R., 2009. Species distribution models: Ecological explanation and prediction across space and time. Annu. Rev. Ecol. Evol., 40: 677-697. https://doi.org/10.1146/annurev. ecolsys.110308.120159

Elith, J., Phillips, S.J., Hastie, T., Dudík, M., Chee, Y.E. and Yates, C.J., 2011. A statistical explanation of
Maxent for ecologists. Divers. Distrib., 17: 43-57. https://doi.org/10.1111/j.1472-4642.2010.00725.x

Fielding, A.H. and Bell, J.F., 1997. A review of methods for the assessment of prediction errors in conservation presence/absence models. Environ. Conserv., 24: 38-49. https://doi.org/10.1017/ S0376892997000088

Fischer, J. and Lindenmayer, D.B., 2000. An assessment of the published results of animal relocations. Biol. Conserv., 96: 1-11. https://doi.org/10.1016/S00063207(00)00048-3

Fonderflick, J., Azama, C., Brochier, C., Cosson, E. and Quékenborn, D., 2015. Testing the relevance of using spatial modeling to predict foraging habitat suitability around bat maternity: A case study in Mediterranean landscape. Biol. Conserv., 192: 120129. https://doi.org/10.1016/j.biocon.2015.09.012

Franklin, J., 2009. Mapping species distributions: Spatial inference and prediction, $1^{\text {st }} \mathrm{ed}$. Cambridge University Press, Cambridge.

Hernandez, P.A., Graham, C.H., Master, L.L. and Albert, D.L., 2006. The effect of sample size and species characteristics on performance of different species distribution modeling methods. Ecography, 29: 773-785. https://doi.org/10.1111/j.09067590.2006.04700.x

Huo, Z.P., Guo, J.F., Li, X. and Yu, X.P., 2014. Postfledging dispersal and habitat use of a reintroduced population of the crested ibis (Nipponia nippon). Avian Res., 5: 7. https://doi.org/10.1186/s40657014-0007-5

IUCN/SSC, 2013. Guidelines for reintroductions and other conservation translocations, Version 1.0. IUCN Species Survival Commission, Gland, Switzerland.

Jin, L.R., He, H.S., Zong, C., Zhou, Y.F. and Bu, R.C., 2008. Effects of different forest management alternatives on Sciurus vulgaris habitat. Chin. J. appl. Ecol., 19: 949-955.

Kebede, F., Moehlman, P.D., Bekele, A. and Evangelista, P.H., 2014. Predicting seasonal habitat suitability for the critically endangered African wild ass in the Danakil, Ethiopia. Afri. J. Ecol., 52: 533-542. https://doi.org/10.1111/aje.12159

Latif, Q.S., Saab, V.A., Mellen-Mclean, K. and Dudley, J.G., 2015. Evaluating habitat suitability models for nesting white-headed woodpeckers in unburned forest. J. Wild. Manage., 79: 263-273. https://doi. org/10.1002/jwmg.842

Li, X.H., Tian, H.D. and Li, D.M., 2009. Why the crested ibis declined in the middle twentieth century. Biodiv. Conserv., 18: 2165-2172. https:// 
doi.org/10.1007/s10531-009-9580-Z

Li, J.Q., Lv, L., Wang, Y., Xi, B. and Zhang, Z.W., 2012. Breeding biology of two sympatric Aegithalos tits with helpers at the nest. J. Ornithol., 153: 273-283. https://doi.org/10.1007/s10336-011-0740-Z

Li, X.H., Li, D.M., Li, Y.M., Ma, Z.J. and Zhai, T.Q., 2002. Habitat evaluation for crested ibis: A GISbased approach. Ecol. Res., 17: 565-573. https:// doi.org/10.1046/j.1440-1703.2002.00515.X

Li, X.H., Li, D.M., Ma, Z.J. and Schneider, D.C., 2006. Nest site use by crested ibis: Dependence of a multifactor model on spatial scale. Landsc. Ecol., 21: 1207-1216. https://doi.org/10.1007/s10980006-0021-z

Liu, D.P., Ding, C.Q. and Chu, G.Z., 2006. Potential breeding sites of crested ibis Nipponia nippon. Acta Zool. Sin., 52: 11-20.

Liu, F., William, J.M. and Li, D.Q., 2017. Correlating habitat suitability with landscape connectivity: A case study of Sichuan golden monkey in China. Ecol. Model., 353: 37-46. https://doi.org/10.1016/j. ecolmodel.2016.09.004

Ma, Z.J., Ding, C.Q. and Li, X.H., 2001. Feeding site selection of crested ibis in winter. Zool. Res., 22: 46-50.

Merow, C., Smith, M.J. and Silander, J.A., 2013. A practical guide to MaxEnt for modeling species' distributions: What it does, and why inputs and settings matter? Ecography, 36: 1058-1069. https:// doi.org/10.1111/j.1600-0587.2013.07872.x

Phillips, S.J., Anderson, R.P. and Schapire, R.E., 2006. Maximum entropy modeling of species geographic distributions. Ecol. Model., 190: 231-259. https:// doi.org/10.1016/j.ecolmodel.2005.03.026

Phillips, S.J. and Miroslav, D., 2008. Modeling of species distributions with MaxEnt: new extensions and a comprehensive evaluation. Ecography, 31: 161-175. https://doi.org/10.1111/j.09067590.2008.5203.x

Sangermano, F., Bol, L., Galvis, P., Gullison, R.E., Hardner, J. and Ross, G., 2015. Habitat suitability and protection status of four species of amphibians in the Dominican Republic. Appl. Geog., 63: 55-65.
Seddon, P.J., Armstrong, D.P. and Maloney, R.F., 2007. Developing the science of reintroduction biology. Conserv. Biol., 21: 303-312. https://oi. org/10.1111/j.1523-1739.2006.00627.x

Swets, J.A., 1988. Measuring the accuracy of diagnostic systems. Science, 240: 1285-1293. https://doi. org/10.1126/science.3287615

Wang, C., Liu, D.P., Qing, B.Q., Ding, H.H., Cui, Y.Y., Ye, Y.X., Lu, J., Yan, L., Ke, L. and Ding, C.Q., 2014. The current population and distribution of wild crested ibis Nipponia nippon. Chin. J. Zool., 49: 666-671.

Wu, J., Zhu, J.G., Wang, K., Cai, D.J., Liu, Y.Y., Bu, Y.Z. and Niu, H.X., 2017. Breeding ecology of a reintroduced population of Crested Ibis (Nipponia nippon) in Henan Province, China. Pakistan J. Zool., 49:2027-2035.

Xi, B., Zhu, J.G., Zhang, K.Y., Du, Z.Y. and Li, H., 2013. The status of breeding birds in Dongzhai National Nature Reserve, Henan Province. Sichuan J. Zool., 32: 932-937.

Yan, W.B., Wang, Q. and Wang, C., 2015. Evaluation of potential breeding habitat distribution with Maxent model for crested ibis in the Qinling-Bashan Region. Chin. J. Zool., 50: 185-193.

Yu, X.P., Chang, X.Y., Li, X., Chen, W.G. and Shi, L., 2009. Return of the crested ibis Nipponia nippon: A reintroduction programme in Shaanxi province, China. Birding Asia, 11: 80-82.

Zhang, H., Gao, J.X., Ma, M.X., Shao, F.Z., Wang, Q., Li, G.Y., Qiu, J. and Zhou, K.X., 2017. Influence of road on breeding habitat of Nipponia nippon based on MaxEnt model. Chin. J. appl. Ecol., 28: 13521359.

Zhang, R.Z., 1997. Distribution of mammalian species in China. China Forestry Publishing House, Beijing.

Zhao, H.F., Luo, L., Chang, X.Y., Gao, X.B., Li, X., Hou, Y.B. and Liu, X.J., 2010. Habitat selection of feeding sites and food abundance of feralized Nipponia nippon in Autumn in Ningshan, Shaanxi. Chin. J. Zool., 45: 83-89. 